\title{
Specific Features of Kimberlite Prospecting in Various Landscape-geological Conditions
}

Zintchouk, N.N., Boris, Y.I., and Stegnitsky, Y.B.

YaGEER\&D CNIGRI, ALROSA Co. Ltd. Chernyshevsky Sh. 7, Mirny, 678170, Sakha (Yakutia), Russia.

Diamond-prospecting works have been carried out on the Siberian Platform for 50 years. In the result about 1000 kimberlite bodies have been discovered here and broad development of placer diamondiferousness in different in age (from modern to Riphean age) collectors of various genetic types has been allocated. Kimberlite bodies mostly are concentrated in the central (Middle Paleozoic, mainly high-diamondiferous pipes) and north-eastern (Mesozoic, low or non-diamondiferous pipes) parts of the platform. On a considerably large area kimberlite bodies are exposed (practically all north-east and smaller half of the platform's centre). These areas are characterized by simple conditions of prospecting and application of a complex of concentrate-mineralogical and geologicgeophysical (magnetometric survey) methods of prospecting unequivocally solves the set tasks, that is, leads to discoveries of kimberlite pipes. The presence of thick crusts of weathering, vari-facial covering Quaternary sedimentations, breccias in carstic funnels and depressions, as well as low-magnetic kimberlites, etc., represent complicating factors. By the present time the areas with such relatively simple geological structure have been almost completely prospected and geologic-explorational works have been transferred to the territories of main industrially diamondiferous regions (Daldyno-Alakitsky, MaloBotuobinsky and Middle-Markhinsky) of the central part of the platform with extremely complicated conditions of prospecting, where discovery of high-diamondiferous kimberlite pipes is expected. Here kimberlites are overburdened by a thick (about $100 \mathrm{~m}$, a sometimes more) layer of vari-facial terrigenous sedimentations of Mesozoic and Upper Paleozoic, intruded in a complicated way by trapp bodies of Lower Triassic with thickness of $80-100 \mathrm{~m}$, seldom more, and haloes of dispersion of kimberlite minerals are reentrained from more ancient collectors, that is, their initial flows of dispersion can be allocated very seldom, only at availability of favourable factors.

That is why applying the same methods of prospecting it is in fact impossible to discover here kimberlite bodies with the same efficiency as it is on the areas with simple conditions of prospecting. In such conditions magnetometric survey practically does not discover magnetic anomalies from kimberlite bodies, and application of concentrate sampling by a definite net (depending on the details of works) allows only to deliniate the haloes of dispersion of diamond indicator-minerals and proper diamonds, determine the direction of terrigenous material's dislocation separately along stratigraphic levels and conditions of their formation. The most complicated by conditions of prospecting is Malo-Botuobinsky region, for the erosional section of kimberlites here is significant: in pre-Late Paleozoic time it constituted $300 \mathrm{~m}$, in pre-Early Jurassic - $40 \mathrm{~m}$ and in Kainozoic - $5 \mathrm{~m}$. Upper Paleozoic sedimentations therewith are developed in north-western part of the region and Lower Jurassic - on all the area of the region. Due to such a large erosional section 
haloes of dispersion of kimberlitic minerals represent mainly reentrained into alluvial and basin sediments from more ancient collectors. Productive levels gravitate to the lower parts of the sections of the revealed stratigraphic subdivisions of Upper Paleozoic and Lower Jurassic. It is there that the main mass of kimberlite minerals concentrate. Occurring above these levels sedimentations of basin and bog-lacustrine facies are mainly burial thicknesses and determining in prospecting relation haloes of dispersion of kimberlitic minerals are not revealed in them. It is also necessary to underline that denudation of the region's rocks in the process of Upper Paleozoic and Lower Jurassic sediments accumulation was extremely insignificant.

This, on the one hand, contributed to possibility of formation in the basement of Upper Paleozoic and Lower Jurassic sedimentations of narrow jets of proluvial-alluvial and proluvial-diluvial genesis - the products of reentrainment of the ancient crust of weathering, and, on the other hand - testifies about buried and to some extent inherited character of relief, that is, about availability of local structures, which have experienced submergence in the process of sedimentations' formation of Upper Paleozoic and Lower Jurassic structural stages. It is these structures that were determining for formation of kimberlitic minerals' haloes of dispersion. It is necessary to look for such flows, their traces can be noticed by individual grains of high degree of conservation in the mass of reentrained kimberlitic minerals of low conservation. However to come across it - is a very complicated affair. That is why it is expedient to apply concentrate sampling to the revealed on the basis of paleogeographic reconstructions paleowatercources of Late Paleozoic and Early Jurassic ages on prospecting lines with small interval between the boreholes. Small volumes of concentrate samples from boreholes of core drilling, as well as reentrained character of kimberlitic minerals' haloes of dispersion, or their absence at all, decrease possibilities of concentrate-mineralogical method of prospecting in this situation and to the forefront come geophysical prospecting methods which are able to "see" a kimberlite body or "initial" train of the erosion from the surface (gravimagnetic exploration, electric prospecting) or in intraborehole space (radiowave sounding, seismic methods), which should be applied on forecasted areas. In the cases when modern watercources drain the borders of the supposed paleouplifts it is expedient to sample the exposed contact of Lower Paleozoic rocks with overlaying thicknesses and try to distinguish the initial flow of dispersion. Core drilling within the allocated by a complex of geologic-geophysical and concentrate-mineralogical indications of perspective sites must be oriented on direct revealing of a kimberlite body or on its train of erosion preserved in the dales of paleorelief, as well as on providing of intraborehole geophysical methods of prospecting, which requires deepening of boreholes some more $50 \mathrm{~m}$ into the carbonate plinth.

Relatively less complicated conditions of prospecting are earmarked in the development field of thick (down to $200 \mathrm{~m}$ ) sedimentations of Upper Paleozoic of Daldyno-Alakitsky region intruded by trapp bodies as well, for the erosional section of kimberlite pipes here is an order lower than in Malo-Botuobinsky region and that is why initial flows of dispersion of indicator-minerals and diamonds preserve. Their allocation makes proper discovery of a primary source of these minerals somewhat easier. 
Specifically complicated conditions of prospecting are earmarked in Middle-Markhinsky region as well, which is located in the zone of connection of south-eastern slope of Anabar anteclise and north-western border of Vilyuy syneclise. Here the products of kimberlite destruction mainly are carried out beyond the boundaries of the region and the pipes which have undergone weathering are buried by fine-granular sediments (clays, aleurites, fine sands), of lagoonal, basin and beach-submarine genesis. All these did not contribute to the formation and preservation of dispersion haloes of indicator-minerals and proper diamonds in these sediments around pipes, and the weathered kimberlite of lowmagnetic pipes, as a rule with small content of initial minerals and overlayed by sedimentations of Lower Jurassic with the thickness of 80-100 m, does not manifest in geophysical fields, which seriously complicates prospecting of primary deposits of diamonds by the applied complex of geologic-geophysical methods. In this situation determination of availability of secondary and argillaceous kimberlitic minerals in overlaying sedimentations, as well as the search for preserved fragments of kimberlites' crusts of weathering and the products of their close reentrainment come to the first plan. It is necessary to pay special attention therewith to accurate geological description of resources and comprehesively explore composition of clays, specific features of composition and typomorphosis of accessories, geochemical indications of these sedimentations, for high-ripened argillaceous levels of the weathering crust usually completely lose structure-textural specific features of mother rocks, kimberlites including. At the same time the discovery of linear weathering crusts' fragments in faults and the traces of shallow ancient paleowatercources with the products of their close reentrainment even on open and denudated north-western area of the region, composed only by terrigenous-carbonate rocks of Lower Paleozoic, testifies about possibility of finding at more detailed mapping on perspective areas of similar fragments of such structures close to the contact with the field of development of overlaying Jurassic sedimentary thicknesses and trace then under these sedimentations with the help of geophysical methods (gravimetry, electric prospecting, seismic and other methods). 